\title{
Contribution from biogenic organic compounds to particle growth during the 2010 BEACHON-ROCS campaign in a Colorado temperate needleleaf forest
}

\author{
L. Zhou ${ }^{1,2}$, R. Gierens ${ }^{1}$, A. Sogachev ${ }^{3}$, D. Mogensen ${ }^{1}$, J. Ortega ${ }^{4}$, J. N. Smith ${ }^{4,5}$, P. C. Harley ${ }^{4}$, A. J. Prenni ${ }^{6}$, \\ E. J. T. Levin ${ }^{7}$, A. Turnipseed ${ }^{4}$, A. Rusanen ${ }^{1}$, S. Smolander ${ }^{1,8}$, A. B. Guenther ${ }^{9}$, M. Kulmala ${ }^{1}$, T. Karl ${ }^{10}$, and M. Boy ${ }^{1}$ \\ ${ }^{1}$ Department of Physics, P.O. Box 64, 00014 University of Helsinki, Helsinki, Finland \\ ${ }^{2}$ Helsinki University Centre of Environment, P.O. Box 65, 00014 University of Helsinki, Helsinki, Finland \\ ${ }^{3}$ Department of Wind Energy, Technical University of Denmark, Frederiksborgvej 399, P.O. Box 49, Building 118, \\ 4000 Roskilde, Denmark \\ ${ }^{4}$ National Center for Atmospheric Research, Boulder, Colorado, USA \\ ${ }^{5}$ Department of Applied Physics, University of Eastern Finland, 70211 Kuopio, Finland \\ ${ }^{6}$ National Park Service, Air Resources Division, Lakewood, CO, USA \\ ${ }^{7}$ Department of Atmospheric Science, Colorado State University, Fort Collins, CO, USA \\ ${ }^{8}$ NOAA/Geophysical Fluid Dynamics Laboratory, Princeton University Cooperative Institute for Climate Science, Princeton, \\ NJ, USA \\ ${ }^{9}$ Atmospheric Sciences and Global Change Division, Pacific Northwest National Laboratory, Richland, Washington, USA \\ ${ }^{10}$ University of Innsbruck, Institute for Meteorology and Geophysics (IMGI), Innrain 52, 6020 Innsbruck, Austria
}

Correspondence to: L. Zhou (luxi.zhou@helsinki.fi)

Received: 3 March 2015 - Published in Atmos. Chem. Phys. Discuss.: 25 March 2015

Revised: 13 July 2015 - Accepted: 18 July 2015 - Published: 6 August 2015

\begin{abstract}
New particle formation (NPF) is an important atmospheric phenomenon. During an NPF event, particles first form by nucleation and then grow further in size. The growth step is crucial because it controls the number of particles that can become cloud condensation nuclei. Among various physical and chemical processes contributing to particle growth, condensation by organic vapors has been suggested as important. In order to better understand the influence of biogenic emissions on particle growth, we carried out modeling studies of NPF events during the BEACHON-ROCS (Biohydro-atmosphere interactions of Energy, Aerosol, Carbon, H2O, Organics \& Nitrogen - Rocky Mountain Organic Carbon Study) campaign at Manitou Experimental Forest Observatory in Colorado, USA. The site is representative of the semi-arid western USA. With the latest Criegee intermediate reaction rates implemented in the chemistry scheme, the model underestimates sulfuric acid concentration by $50 \%$, suggesting either missing sources of atmospheric sulfuric acid or an overestimated sink term. The results emphasize the
\end{abstract}

contribution from biogenic volatile organic compound emissions to particle growth by demonstrating the effects of the oxidation products of monoterpenes and 2-Methyl-3-buten2-ol (MBO). Monoterpene oxidation products are shown to influence the nighttime particle loadings significantly, while their concentrations are insufficient to grow the particles during the day. The growth of ultrafine particles in the daytime appears to be closely related to the $\mathrm{OH}$ oxidation products of MBO.

\section{Introduction}

Atmospheric aerosols have the potential to change the climate as they influence the Earth's radiative balance as well as the hydrological cycle (e.g., Lohmann and Feichter, 2005; Kerminen et al., 2005). Apart from their climatic influences, aerosols reduce visibility and impact health. Therefore it is important to understand the life cycle of atmospheric 
aerosols and estimate their impacts on climate and health. One important phenomenon associated with the atmospheric aerosol system is new particle formation (NPF) (Kulmala et al., 2004b). During a NPF event, particles first form from nucleation. The exact mechanism behind nucleation is still unclear, but various studies have suggested possible nucleation compounds including water, sulfuric acid, ammonia, and organic compounds (Zhang et al., 2004; Sipilä et al., 2010; Kirkby et al., 2011; Schobesberger et al., 2013). The nucleated particles then grow further via various processes including condensation of vapors and coagulation (Kulmala et al., 2004a; Kulmala and Kerminen, 2008; Kerminen et al., 2010). This growth step determines the formation rate of detectable particles (usually $>3 \mathrm{~nm}$ ) as well as the impact of NPF on cloud condensation nuclei populations (Kulmala et al., 2013). Organic compounds are the main drivers of the growth step and are thus critical for aerosol formation (Kerminen et al., 2000; Sellegri et al., 2005; Boy et al., 2005; Allan et al., 2006; Laaksonen et al., 2008; Ehn et al., 2014).

Volatile organic compounds (VOCs) are of both anthropogenic and biogenic origin. Vegetation produces biogenic volatile organic compounds (BVOCs) for a variety of physiological purposes (e.g., Fuentes et al., 2000; Sharkey et al., 2008). There are complex mechanisms that control BVOC emissions. The emission abundance and chemical speciation varies by vegetation species as well as environmental conditions such as light and temperature. Since the first enclosure study of BVOC emissions in the late 1920s (Isidorov, 1990), numerous assessments by lab experiments and field measurements have been carried out to quantify BVOC emissions. The global BVOC emissions by terrestrial ecosystems are estimated to be about $1000 \mathrm{Tg} \mathrm{Cyr}^{-1}$, of which about $50 \%$ is isoprene and $15 \%$ is monoterpenes (Guenther et al., 2012). This is nearly 8 times the global VOC emissions of anthropogenic origin, which are estimated to be about $130 \mathrm{Tg} \mathrm{C} \mathrm{yr}^{-1}$ (Lamarque et al., 2010).

The impact of these huge BVOC emissions is of great scientific interest. Apart from their potential impacts on air quality (Andreae and Crutzen, 1997; Atkinson, 2000), BVOCs are known to affect the climate system by contributing to aerosol formation and growth. However, the understanding of how BVOCs contribute to aerosol formation is incomplete. The vast amount of different BVOC species, numerous atmospheric chemistry reaction pathways and uncertain microphysics make a complete understanding of these processes very difficult. Many studies have suggested the condensing organic compounds to be nonvolatile or have extremely low volatility (Spracklen et al., 2011; Riipinen et al., 2011; Donahue et al., 2011; Kulmala et al., 2013). For example, Ehn et al. (2014) investigated extremely low volatility organic compounds (ELVOCs) arising from monoterpene oxidation, which has been predicted by Kulmala et al. (1998) to enhance the condensational growth of aerosols in chamber experiments under atmospherically relevant conditions. This study has supplemented the link between secondary organic aerosol (SOA) formation and one of the most abundant families of BVOCs, monoterpenes. Besides monoterpenes, 2Methyl-3-buten-2-ol (MBO), another important BVOC emitted by pine trees in western North America (Harley et al., 1998), is also a potential precursor of SOA (Chan et al., 2009). Recent smog chamber studies and field measurements revealed that $\mathrm{OH}$-initiated oxidation of $\mathrm{MBO}$ leads to SOA formation (Zhang et al., 2012, 2014).

Building on past research about the role of organic compounds in new particle formation, we aim to study in particular the influence of biogenic organic compounds on particle growth via a modeling approach. This modeling activity was conducted for the Bio-hydro-atmosphere interactions of Energy, Aerosol, Carbon, H2O, Organics \& Nitrogen - Rocky Mountain Organic Carbon Study (BEACHON-ROCS) field campaign at the Manitou Experimental Forest Observatory (MEFO) during August 2010 (Ortega et al., 2014). The campaign focused on the biosphere-atmosphere exchange of reactive organic gases and thus provided an excellent data set of aerosol precursor gases. The Manitou Experimental Forest Observatory is a mountainous forest site in close proximity to human activity. It provides an opportunity to study biogenic SOA formation at a rural-urban interface (Cui et al., 2014). Various studies have indicated that biogenic SOA formation in forest environments can be enhanced by the inflow of anthropogenic pollutants (Boy et al., 2008; Hoyle et al., 2011; Jung et al., 2013). The modeling tool used in this study is the chemical-transport column model SOSAA (model to Simulate Organic vapors, Sulfuric Acid and Aerosols; Boy et al., 2011; Zhou et al., 2014). Despite the limitation for simulating horizontal transport, this process-orientated model is valuable for gaining detailed understanding of local phenomena. Due to the complex terrain at the Manitou site, the first task in this study was to assess the accuracy of reconstructing the highly variable meteorological conditions using a column model. The second task was to compare the modeled aerosol precursor gases against the measurements. In addition to sulfuric acid $\left(\mathrm{H}_{2} \mathrm{SO}_{4}\right)$, we focused on $\mathrm{MBO}$ and monoterpenes because they dominate the biogenic emissions at the site (Karl et al., 2014; Kaser et al., 2013a, b; Kim et al., 2010). After assessing the model performance with respect to the meteorology and related precursor gases, we proceeded with the study on the effects of BVOCs and their oxidation products on particle growth.

\section{Materials and methods}

\subsection{Manitou Experimental Forest Observatory and BEACHON-ROCS field campaign}

All observations presented in this study were obtained during the BEACHON-ROCS field campaign at Manitou Experimental Forest Observatory in August 2010. The campaign is part of the BEACHON project, which aims to investigate 
ecosystem-atmosphere exchange of trace gases and aerosols and their potential feedbacks between biogeochemical and hydrological cycles. Ortega et al. (2014) have provided a very detailed description of the BEACHON project as well as MEFO; here we only provide a summary of the site and campaign descriptions related to this study.

MEFO is located in the Front Range of the Colorado Rocky Mountains $\left(39.1^{\circ} \mathrm{N}, 105.1^{\circ} \mathrm{W} ; 2370 \mathrm{~m}\right.$ above sea level). It is a mountainous site in close proximity to large urban centers (e.g., Denver is about $85 \mathrm{~km}$ northeast of the site, and Colorado Springs about $40 \mathrm{~km}$ to the southeast). Due to shielding by the Rampart Range to the east and Pikes Peak to the south, the site normally encounters clean continental air masses from the southwest. Exceptions include episodic but frequent intrusions of anthropogenic air masses due to upslope flow during the mornings and air moving downslope from the south during the evenings. Ponderosa pine is the dominant tree species at the forested site. The median tree age at the site was 49.5 years and the average canopy height was about $18.5 \mathrm{~m}$ in 2010 (DiGangi et al., 2011). Approximately $50 \%$ of the precipitation falls as rain during the summer season (June-September), primarily during afternoon thunderstorms characterized by brief but intense periods of rainfall and lightning. The site is representative for the semiarid western USA, where biosphere-atmosphere exchange processes of energy, water, carbon, and nitrogen are sensitive to the amount of precipitation.

Measurements of VOCs used a valve-switching system which changed sampling lines every $5 \mathrm{~min}$ and cycled through six Teflon inlets mounted at 1.6, 5.0, 12.0, 17.7, and $25.1 \mathrm{~m}$ over a $30 \mathrm{~min}$ period. VOC concentrations were measured by a proton-transfer-reaction mass spectrometer (PTRMS, Ionicon Analytik GmbH). The instrument is based on soft chemical ionization using protonated water ions $\left(\mathrm{H}_{3} \mathrm{O}^{+}\right)$ (Hansel et al., 1995; Lindinger et al., 1998). Other tracegas measurements from the measurement mast include $\mathrm{CO}$, $\mathrm{CO}_{2}$, water vapor, $\mathrm{NO}, \mathrm{NO}_{2}, \mathrm{O}_{3}$ and $\mathrm{SO}_{2}$. The mast was also equipped with sonic anemometers as well as temperature and radiation probes for continuous meteorological measurements and for observing turbulent fluxes using a closedpath eddy covariance system. Detailed descriptions of the flux and concentration measurements of VOCs are presented in Kaser et al. (2013b). Sulfuric acid and $\mathrm{OH}$ concentrations were measured using chemical-ionization mass spectrometry (CIMS) (Tanner et al., 1997). The inlet was $2.7 \mathrm{~m}$ above ground level, facing perpendicular to the primary wind direction. The uncertainties for $\mathrm{H}_{2} \mathrm{SO}_{4}$ measurements are estimated to be 30-60 \% (Plass-Dülmer et al., 2011). The uncertainties for $\mathrm{OH}$ measurements are estimated as $35 \%$ with a detection limit at $4 \times 10^{5}$ molecules $\mathrm{cm}^{-3}$ (Kim et al., 2013). Downwelling $\mathrm{NO}_{2}$ photolysis rates were measured by filter radiometers (Meteorologie Consult GmbH, Junkermann et al., 1989) at the top of the chemistry measurement mast. The ratio of downwelling to upwelling $\mathrm{NO}_{2}$ photolysis rate was measured on 10 August 2010. The ratio was then used to estimate the total $\mathrm{NO}_{2}$ photolysis rate for the rest of the campaign period (DiGangi et al., 2011).

Dry-particle size distribution measurements between 15 and $350 \mathrm{~nm}$ were made at ground level using a differential mobility particle sizer (DMPS) during the campaign period. Sample flow first passed through a diffusion drier and a bipolar charge neutralizer (Aerosol Dynamics Inc.), containing four ${ }^{210}$ Po strips (NRD Staticmaster 2U500). Particles were then size-selected using a differential mobility analyzer (DMA; TSI 3071) and counted with a condensation particle counter (CPC; TSI 3010). The DMA stepped through 20 dry-particle diameters chosen such that $\operatorname{dlog}_{10} D_{\mathrm{p}}$ remained constant. Measurements were made at each size setting for $30 \mathrm{~s}$.

The NCAR GPS Advanced Upper-Air Sounding System (GAUS) launched sondes to investigate the evolution of the boundary layer. The measurements are available from $12 \mathrm{Au}-$ gust at noon to 14 August 2010 at noon and from 21 August at noon to 23 August 2010 at noon. The interval between each measurement point is either 1 or $2 \mathrm{~h}$.

\subsection{SOSAA model}

The SOSAA model is a one-dimensional chemical-transport model with detailed aerosol dynamics. It was constructed to study various processes in the planetary boundary layer in and above a forest canopy, which includes biogenic emissions, vertical transport, air chemistry and aerosol dynamics (Boy et al., 2011; Zhou et al., 2014). The different processes have been modularized so that the model is optimized for implementing various parameterizations. The boundary layer meteorology code is based on the one-dimensional version of SCADIS (SCAlar DIStribution; Sogachev et al., 2002, 2012). The emission module in the model is based on MEGAN (Model of Emissions of Gases and Aerosols from Nature; Guenther et al., 2006). The chemical mechanism scheme is produced by selecting chemical reactions primarily from the Master Chemical Mechanism, MCM v3.2 (Jenkin et al., 1997, 2012; Saunders et al., 2003), via the website http://mcm.leeds.ac.uk/MCM. The selected chemical reactions are processed using the KPP - kinetic preprocessor (Damian et al., 2002). The chemical scheme accommodates great flexibility in selecting desired reactions. The aerosol module in SOSAA is based on the aerosol dynamics model UHMA, which is a sectional box model developed for studies of tropospheric new particle formation and growth under clear-sky conditions (Korhonen et al., 2004). It includes all basic aerosol processes, including nucleation, condensation, coagulation and dry deposition. The model performance has been validated against field measurements from Hyytiälä, Finland, in various studies (Boy et al., 2013; Mogensen et al., 2011, 2015; Smolander et al., 2014).

The biogenic emission module based on MEGAN requires emission factors for representative vegetation types to estimate the net fluxes of BVOCs from canopy to the atmo- 
sphere. The emission factors define the emission of a given compound at standard conditions and have an uncertainty of a factor of 3 or more when global default values are used, primarily due to the large variability in emission rates for different plants (Guenther et al., 1995). In this study monoterpene emission factors were obtained from leaf cuvette measurements (Harley et al., 2014), while the MBO emission factor is suggested by Kaser et al. (2013a), which is based on both leaf cuvette emission measurements and canopy-scale analysis.

The chemistry scheme employed by the model for this study includes the full MCM chemical paths for the following parent molecules: methane, methanol, formaldehyde, acetone, acetaldehyde, MBO, isoprene, alpha-pinene, betapinene, limonene and beta-caryophyllene. For other emitted organic compounds, for which no MCM chemistry path is available, we have included their first-order oxidation reactions with $\mathrm{OH}, \mathrm{O}_{3}$ and $\mathrm{NO}_{3}$. Those compounds include myrcene, sabinene, 3-carene, ocimene, cineole and "other" monoterpenes, and farnesene and "other" sesquiterpenes (Atkinson, 1994). In the case of linalool we have included its reaction with $\mathrm{OH}$ and $\mathrm{NO}_{3}$ to form acetone and "condensable material" and its reaction with $\mathrm{O}_{3}$ to additionally produce formaldehyde. For the reactions of the stabilized Criegee intermediates (sCI) from alpha- and beta-pinene and limonene, we used the rates from Mauldin III et al. (2012), similar to "Scenario C" in Boy et al. (2013). For the sCI from isoprene, we used the rates from Welz et al. (2012) as done in "Scenario D" in Boy et al. (2013). Sulfuric acid and nitric acid are removed from the gas phase based on the condensation sinks calculated from background aerosol loading.

It is not fully understood which mechanisms drive nucleation in the atmosphere. Various parameterizations have been created for predicting atmospheric nucleation (e.g., Pierce and Adams, 2009; Paasonen et al., 2010). The nucleation mechanism, however, has minor influence on the actual production rate of the observable particles compared to the subsequent growth step because the nucleated clusters have rather short lifetimes (Kulmala and Kerminen, 2008; Kulmala et al., 2013). For this reason, we opted to use only the kinetic nucleation parameterization in this study (Weber et al., 1997). It was chosen also because Zhou et al. (2014) showed that the SOSAA model with kinetic nucleation parameterization gave good predictions of NPF events at a boreal forest site in Hyytiälä, Finland. In kinetic nucleation, two sulfuric acid molecules collide to form a cluster as in the kinetic gas theory. Some of the formed clusters will break apart, but some will remain stable and then grow to become particles. The nucleation rate, $J$, is related to the sulfuric acid concentration, $\left[\mathrm{H}_{2} \mathrm{SO}_{4}\right]$, via

$J=K \cdot\left[\mathrm{H}_{2} \mathrm{SO}_{4}\right]^{2}$,

where $K$ is the kinetic coefficient that includes both the collision frequency and the probability of forming a stable cluster after the collision (Weber et al., 1997; Sihto et al., 2006; Zhou et al., 2014). The nucleated particles were then added to the first size bin (at $2 \mathrm{~nm}$ ) in the model. Before carrying out our modeling studies for particle growth, a sensitivity study was done to establish a suitable value for the nucleation coefficient $K$. As a result of comparing the simulated and DMPSmeasured total number concentrations for particles between 20 and $80 \mathrm{~nm}, K$ was set to $5 \times 10^{-15} \mathrm{~cm}^{-3} \mathrm{~s}^{-1}$.

The SOSAA model requires four groups of input data. The first group includes the site land cover characteristics, such as the leaf density and canopy height. The second group consists of meteorological parameters, including radiation, vertical profiles of wind speed, temperature and relative humidity (RH). These inputs are available from the micrometeorology mast measurements at MEFO. ERA-Interim reanalysis data by ECMWF (Dee et al., 2011) for wind speed, temperature and humidity were used as the boundary conditions for the upper border of the model column. Since one of the radiation inputs, the actinic flux spectrum, was not measured at MEFO, we used the scaled actinic flux spectrum from the Tropospheric Ultraviolet and Visible (TUV) Radiation Model (Madronich, 1993). The scaling factors are based on the measured $\mathrm{NO}_{2}$ photolysis rates and the TUV-modeled rates (Madronich and Flocke, 1998). The third group consists of five inorganic gas concentrations $\left(\mathrm{NO}, \mathrm{NO}_{2}, \mathrm{CO}, \mathrm{O}_{3}\right.$ and $\mathrm{SO}_{2}$ ) measured from the chemistry measurement mast and the sulfuric acid sink to the background particles. The condensation sink of sulfuric acid was calculated based on the method described by Pirjola et al. (1999). These parameters were read in every half hour with a linear interpolation in between. The last group of input data is the measured particle number size distribution. The model only reads in the measured number size distribution once a day at midnight for initialization. More detailed description of model input is available from Boy et al. (2011).

\subsection{Modeling experiments}

In order to investigate the influence of organics on particle growth, three organic vapors (vapors I-III) were set to take part in the condensation process in addition to sulfuric acid. Since the main biogenic emissions at the site are MBO and monoterpenes, vapors I-III were set to be the lumped sums of first stable reaction products from $\mathrm{OH}, \mathrm{O}_{3}$ and $\mathrm{NO}_{3}$ oxidation of MBO and/or monoterpenes. This treatment of organic condensing vapors is similar to the approach of Lauros et al. (2011) and Zhou et al. (2014). Three model experiments were designed to study the influence of MBO and monoterpenes on particle growth:

- Experiment I: lumped sums of first stable reaction products from $\mathrm{OH}, \mathrm{O}_{3}$, and $\mathrm{NO}_{3}$ oxidation of monoterpenes were included as the organic condensing vapor I, II, and III, respectively.

- Experiment II: lumped sums of first stable reaction products from $\mathrm{OH}, \mathrm{O}_{3}$, and $\mathrm{NO}_{3}$ oxidation of $\mathrm{MBO}$ 

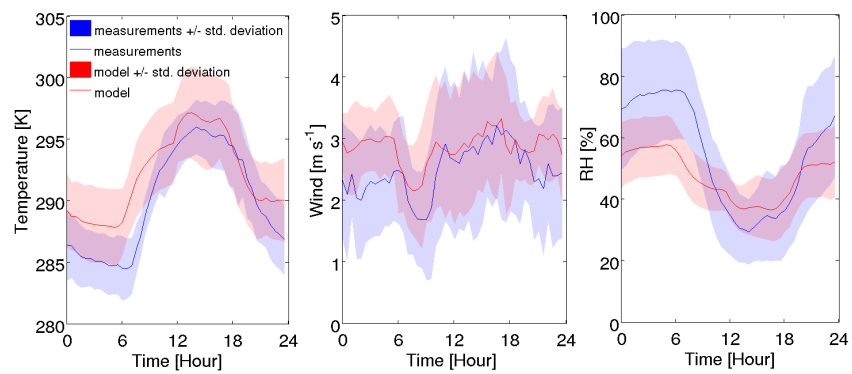

Figure 1. Averaged modeled and measured diurnal cycles of temperature (left), wind speed (middle), and relative humidity ( $\mathrm{RH}$, right). Measurement average (line) and \pm 1 standard deviation (shaded area) are in blue; model average (line) and \pm 1 standard deviation are in red. The comparisons are made above canopy at $30 \mathrm{~m}$.

were included as the organic condensing vapor I, II, and III, respectively.

- Experiment III: lumped sums of first stable reaction products from $\mathrm{OH}$ oxidation of both monoterpenes and MBO were included as the organic condensing vapor I. Lumped sums of first stable reaction products from $\mathrm{O}_{3}$ and $\mathrm{NO}_{3}$ oxidation of monoterpenes were included as the organic condensing vapors II and III, which were the same as vapors II and III in experiment I.

The aerosol module simulates particle growth by calculating the condensation flux of each condensing vapor onto the particle surfaces (Korhonen et al., 2004). An iterative method was used in each experiment to estimate the saturation vapor concentration of the condensing organic vapors, by varying the saturation vapor pressure of each compound and by comparing the modeled particle size distribution with the observed distribution. In all experiments, sulfuric acid condenses onto particles with the assumption that, once it is condensed, it will not evaporate from the particles.

\section{Model validation for meteorology and chemistry}

Since the SOSAA model does not accommodate precipitation, all the observational data presented in this section have been filtered to exclude rain events. When comparing averaged diurnal profiles of a specific parameter, the modeled profile is the average of the period for which observation data are available.

\subsection{Meteorology}

Figure 1 presents the average behavior of the modeled temperature, wind speed and relative humidity compared to the measurements above the canopy at $30 \mathrm{~m}$. Because the site is situated in a north-south slope (draining to the north), the meteorology is influenced by the diurnal mountain-valley

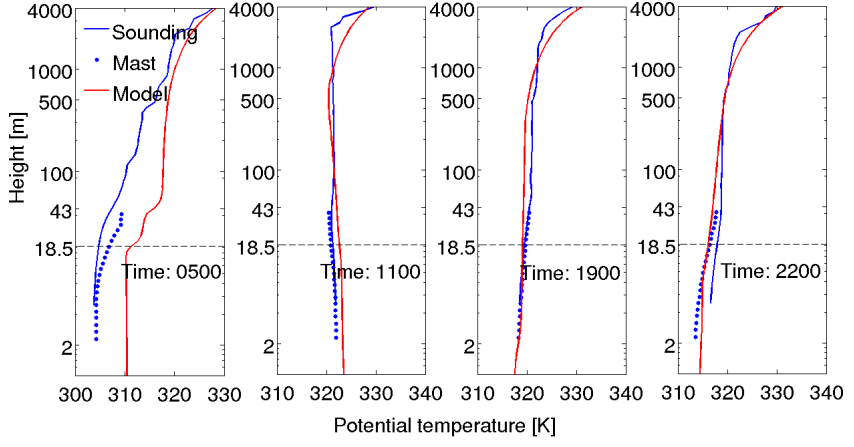

Figure 2. Observed and modeled vertical profiles of potential temperature at different time on 22 August 2010 (DOY 234). The $y$ axis (height) is in logarithmic scale.

flows. While daytime wind directions are variable, nighttime winds are dominated by the drainage from the south (Ortega et al., 2014). Unfortunately the column model SOSAA cannot capture this behavior related to the topography. The model simulates a comparable temperature for daytime but fails to decrease the temperature sufficiently during nighttime. The big diurnal variation applies not only to the temperature but also to the relative humidity. The model again simulates comparable RH levels during the day but fails to capture it at night. The underestimation in $\mathrm{RH}$ at night is mainly a result of the overestimation of temperature. The simulated wind speed agrees well with the measurements during daytime. At night, the wind speed was observed to fluctuate around $2 \mathrm{~m} \mathrm{~s}^{-1}$ above the canopy, but the modeled wind speed is around $3 \mathrm{~m} \mathrm{~s}^{-1}$. As already mentioned, the model cannot simulate the drainage flows related to the topography, and a clear discrepancy of the nighttime wind speeds can be expected as the nighttime drainage has been observed to be effective at the site. In general the model gave satisfactory predictions of the three meteorological variables during daytime, though notable deviations are found during nighttime.

Out of the five sounding days, 22 August 2010, day of year (DOY) 234, was selected to demonstrate vertical profiles of the potential temperature at the site (Fig. 2). Mast measurements are provided in addition to sounding data in order to extend the measured profile close to the surface. Mast measurements and sounding measurements differ because (1) the mast observations presented are half-an-hour averages, while the sounding can only provide an instantaneous value; (2) the instruments are not the same (least likely and only has minor contribution to the difference); and (3) measurements were not made at exactly the same location. At 05:00:00 LT, both the model and measurements show a typical nocturnal stable boundary layer. We focus on the gradient of potential temperature that describes the stability. The model exhibits a stronger gradient at the canopy top $(18.5 \mathrm{~m}) \mathrm{com}$ pared to both the mast measurements and the sounding ob- 

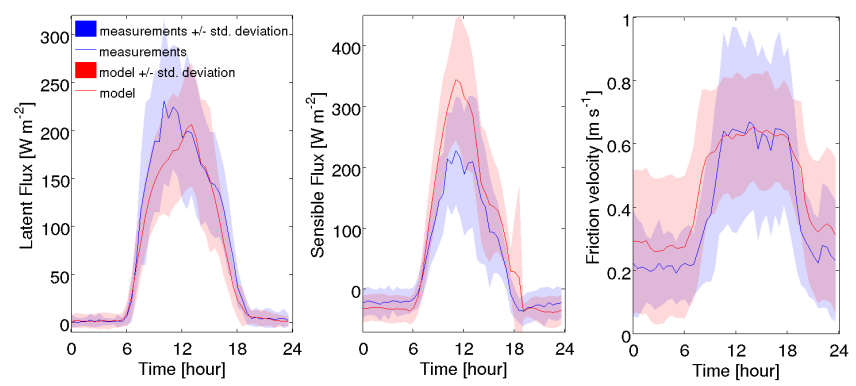

Figure 3. Averaged modeled and measured diurnal cycles of latent heat flux (left), sensible heat flux (middle) and friction velocity (right). Measurement average (line) and \pm 1 standard deviation (shaded area) are in blue; model average (line) and \pm 1 standard deviation (shaded area) are in red. The comparison is made above the canopy at $30 \mathrm{~m}$.

servation. The modeled profile improves during daytime. At 11:00:00 LT, the boundary layer has developed since morning up to about $800 \mathrm{~m}$ in the model, while the sounding data show it may be higher than $1 \mathrm{~km}$. The simulated potential temperature gradient near the ground is similar to the mast measurements, despite a slight difference in magnitude. At 19:00:00 LT, the gradients have already become positive. The strongest gradient modeled is again a few hundred meters lower than the sounding data. This tendency of SOSAA to slightly underestimate the height of the mixed layer has also been observed in studies made in Hyytiälä, Finland (Mogensen et al., 2015). At 22:00:00 LT, the nocturnal boundary layer has built up. We see the model profile shows a gradient below the canopy at around $10 \mathrm{~m}$, indicating an inversion inside the canopy. The sounding measurements show strongest potential temperature gradient above the canopy. In general, despite the underestimated daytime boundary layer height, the model at least predicted a satisfactory potential temperature profile up to the top of the measurement mast.

To investigate the model performance with respect to the surface energy balance and the vertical mixing strength, we compared the modeled average diurnal profile of the latent and sensible heat fluxes and friction velocity with the eddy covariance measurements above canopy (Fig. 3). A positive flux indicates that the atmosphere is gaining heat from the surface and vice versa for the negative flux. The modeled latent heat flux is in general comparable with observations except during morning, when the model underestimates the fluxes slightly. The sensible heat flux is in general overestimated during daytime. This is probably related to inaccuracies of the other components of the energy balance, namely the heat flux and storage to the soil and the net radiation. These can also cause the leaf temperature to be modeled incorrectly, which promotes the simulated sensible heat flux. The friction velocity is well simulated compared to the measurements during daytime. The nighttime overestimation is due to the overestimation of wind speed (Fig. 1), which in-
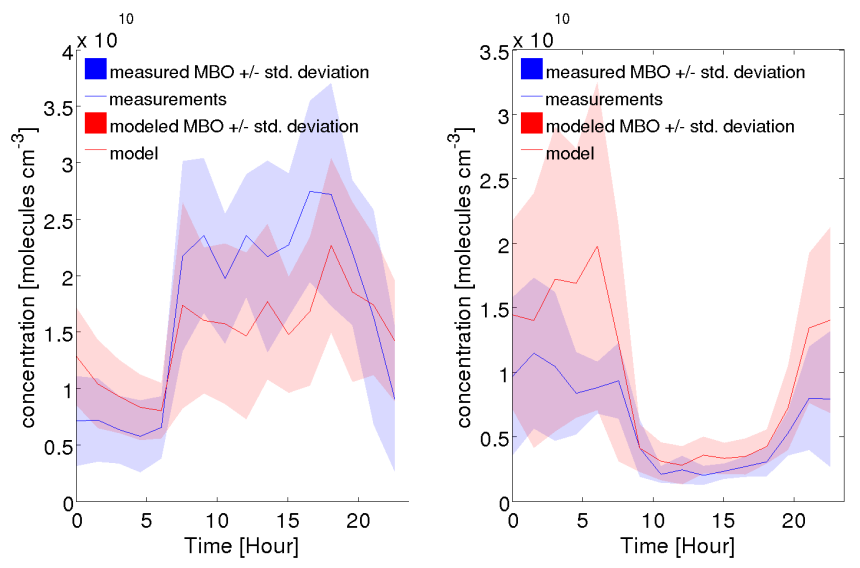

Figure 4. Averaged modeled and measured diurnal cycles of $\mathrm{MBO}$ (left) and monoterpene (MT, right) concentrations. Measurement average (line) and \pm 1 standard deviation (shaded area) are in blue; model average (line) and \pm 1 standard deviation (shaded area) are in red. The comparison is made at $3.5 \mathrm{~m}$.

creases vertical wind shear and thus the amount of turbulent mixing. The well-modeled friction velocity suggests that the model should have reasonable vertical turbulence mixing.

To summarize, the model's meteorological performance is satisfactory during daytime. The simulated basic meteorological parameters (temperature and its gradient, humidity, and wind speed) as well as the turbulent fluxes of latent heat and momentum (which directly depends on the magnitude of the friction velocity presented in Fig. 3) agree well with the observations. The height of the boundary layer, which dictates the volume of air into which the emitted compounds are diluted, had a tendency to be underestimated by around $20 \%$. As the difference relative to the total boundary layer height is not large, this is not expected to have a large impact. However, during nighttime the drainage flows down the side of the mountain cause difficulties for the model to simulate the meteorological conditions. We therefore focus on daytime conditions in the following analysis.

\subsection{Chemistry}

The chemistry analysis focuses on aerosol precursor gases (MBO, monoterpenes and sulfuric acid), $\mathrm{OH}$ and the oxidation products of $\mathrm{MBO}$ and monoterpenes. Averaged diurnal concentrations are presented in this section to show the general behavior of modeled chemistry. The averages are made for the periods of 13-14 and 16-13 August 2015, when the measurements of all species mentioned above are available.

The averaged diurnal profiles show that the monoterpene concentration has a clear diurnal variation in both the observations and model simulation (Fig. 4). The concentration is high during the night and low during the day. The nighttime concentration is high mainly due to the suppressed boundary layer height and the decreased losses from oxidation. On the 


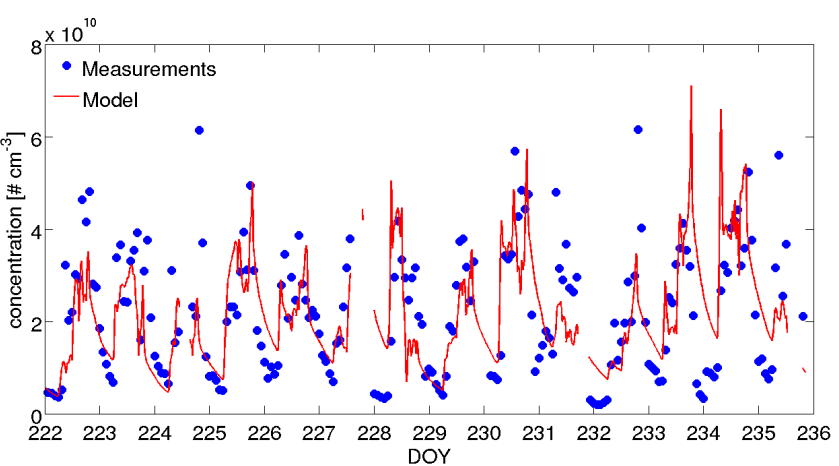

Figure 5. Measured and modeled MBO concentration at $3.5 \mathrm{~m}$.

other hand, the concentration decreases during daytime as the boundary layer height increases and due to the presence of $\mathrm{OH}$. The model simulated comparable concentrations but an increasing trend for MT during nighttime. The main reason could be that the model overestimated the nighttime temperature up to $5^{\circ}$, which possibly leads to overestimation of monoterpene emissions. Sensitivity studies have been conducted for the response of total monoterpene emission rate to temperature. An increase of $5{ }^{\circ} \mathrm{C}$ in the night may increase the emission rates by 80 to $100 \%$. On average the simulated monoterpene concentration during daytime agrees well with the measurement (Fig. 4). The MBO concentration is high during daytime and low during nighttime due to the lightdependent production. The model captures the diurnal trend of MBO concentration well (Fig. 4). The simulated daytime MBO concentration is about 20 to $25 \%$ lower than the observation, which slightly exceeds the instrument uncertainty of $20 \%$. Because of the large standard deviations of the measurement data set, Fig. 5 presents the modeled and measured MBO concentrations from 10 to 23 August 2010 (DOY 222 to 235). It shows that the modeled concentration is comparable to the measurement except during some nights when the concentration is overestimated.

The modeled average diurnal profile of $\mathrm{OH}$ is in good agreement with the observations before noon (Fig. 6). After this time, the model results become higher than the observations, which should result from (1) missing sinks and (2) overestimated production. The missing sink terms have been studied previously at MEFO by Nakashima et al. (2014). Based on measurements, Nakashima et al. (2014) concluded a missing $\mathrm{OH}$ reactivity of $29.5 \%$, which may mainly be due to oxidized products of biogenic species. Mogensen et al. (2011) also concluded missing $\mathrm{OH}$ reactivity of more than $50 \%$ in a boreal forest environment in southern Finland. In addition to unknown missing sinks, the underestimated $\mathrm{MBO}$ concentrations may also contribute to the overestimated MBO. We suspect the photolysis production of $\mathrm{OH}$ may be overestimated due to the method in scaling the actinic flux spectrum. Though the modeled $\mathrm{NO}_{2}$ photolysis rate is within a measurement uncertainty of 10 to $20 \%$ (Seroji et
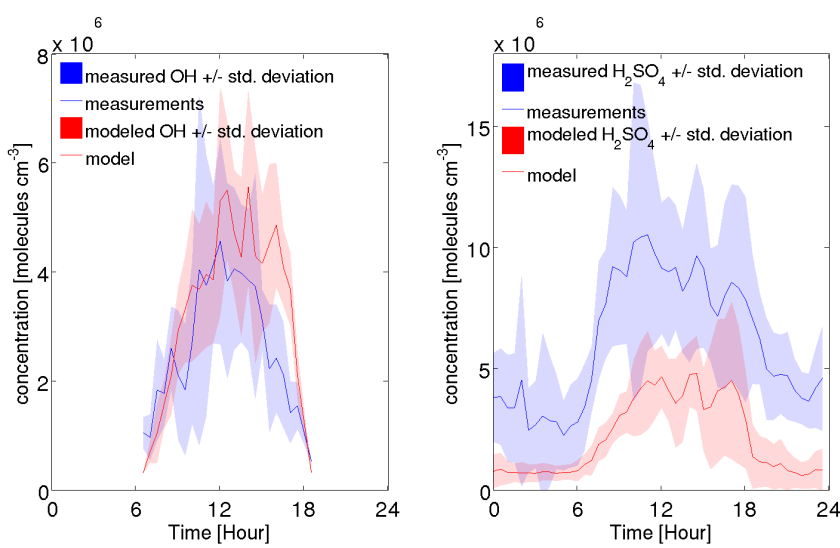

Figure 6. Averaged modeled and measured diurnal cycles of $\mathrm{OH}$ concentration (left) and sulfuric acid concentration (right). Measurement average (line) and \pm 1 standard deviations (shaded area) are in blue; model average (line) and \pm 1 standard deviations (shaded area) are in red. The comparisons for $\mathrm{OH}$ and sulfuric acid are made at $2 \mathrm{~m}$.

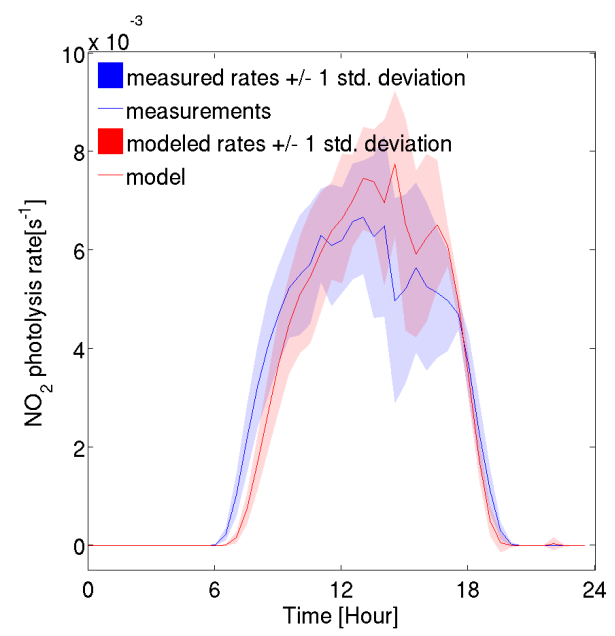

Figure 7. Averaged modeled and measured diurnal cycles of photolysis rate $\mathrm{NO}_{2}$. Measurement average (line) and \pm 1 standard deviations (shaded area) are in blue; model average (line) and \pm 1 standard deviations (shaded area) are in red. The comparison for photolysis rate is made above the canopy at $25 \mathrm{~m}$.

al., 2004), it is still possible that the photolysis rate is indeed overestimated in the afternoon, as can be seen in Fig. 7. Except for 13 August 2015, all days in the period for which the averaged profiles are made were cloudy in the afternoon. The deviation in both $\mathrm{OH}$ concentration and $\mathrm{NO}_{2}$ photolysis rate suggest either the molecular parameterizations in predicting photolysis rates or the scaling method in preparing the actinic flux spectrum may be biased during cloudy conditions.

The modeled sulfuric acid concentration is only half of the observed value (Fig. 6). One reason could be that the condensation sink of sulfuric acid is overestimated. Another reason should relate to the unknown sulfuric acid production 

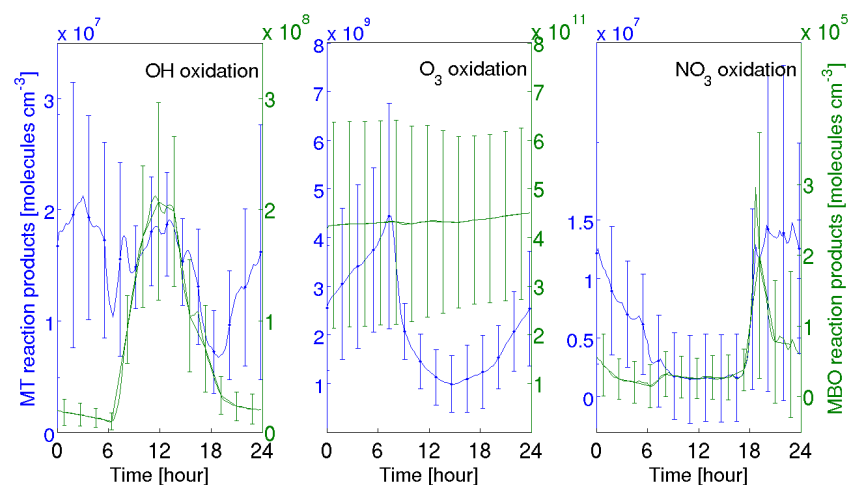

Figure 8. Averaged modeled diurnal cycles of $\mathrm{OH}, \mathrm{O}_{3}$, and $\mathrm{NO}_{3}$ oxidation products of monoterpenes (plotted against left $y$ axis in blue) and MBO (plotted against right $y$ axis in green). The error bars are \pm 1 standard deviation.

term missing from the chemistry scheme (Eisele and Tanner, 1993; Boy et al., 2013; Berresheim et al., 2014). Because the underestimation is observed during both night- and daytime, the missing production term is likely not related to photolysis. It should also be noted that the CIMS measurements may have uncertainties of 30 to $60 \%$ (Plass-Dülmer et al., 2011). Importantly, the diurnal trend in sulfuric acid concentrations is well captured, which is crucial for correctly simulating a new particle formation event.

The modeled diurnal concentration profiles of the sum of first stable reaction products from $\mathrm{OH}, \mathrm{O}_{3}$ and $\mathrm{NO}_{3}$ oxidation of monoterpenes and $\mathrm{MBO}$ are shown in Fig. 8. The list of first stable reaction compounds are listed in Table 2. The concentrations of reaction products from MBO oxidation are 10 to 100 times higher than the concentrations of reaction products from monoterpenes, except in the case of $\mathrm{NO}_{3}$ oxidation. The concentrations of $\mathrm{O}_{3}$ oxidation products are about 2 to 3 orders of magnitude greater than that of $\mathrm{OH}$ oxidation products, irrespective of the precursor species. Comparing to the concentrations of first stable $\mathrm{O}_{3}$ oxidation products of $\mathrm{MBO}$, which are fairly stable at a level of $3-6 \times 10^{11}$ molecules $\mathrm{cm}^{-3}$, the concentrations of $\mathrm{NO}_{3}$ oxidation products of $\mathrm{MBO}$ are negligible. The nighttime concentrations of $\mathrm{NO}_{3}$ oxidation products of monoterpenes are comparable with the daytime concentrations of $\mathrm{OH}$ oxidation products of monoterpenes. The concentrations of $\mathrm{NO}_{3}$ oxidation products of monoterpenes exhibit a clear diurnal trend of the concentrations being high during the night and low during the day, which is explained by the same diurnal trends of $\mathrm{NO}_{3}$ and monoterpenes concentrations. Opposite to the trend of $\mathrm{NO}_{3}$ oxidation products of monoterpenes, the concentrations of $\mathrm{OH}$ oxidation products of $\mathrm{MBO}$ show a clear diurnal profile that peaks at noon and drops during nighttime. Because the fast growth of nucleated clusters often happens during daytime, it is suspected that the $\mathrm{OH}$ oxidation products of MBO may possibly contribute to the early growth of particles at the site.

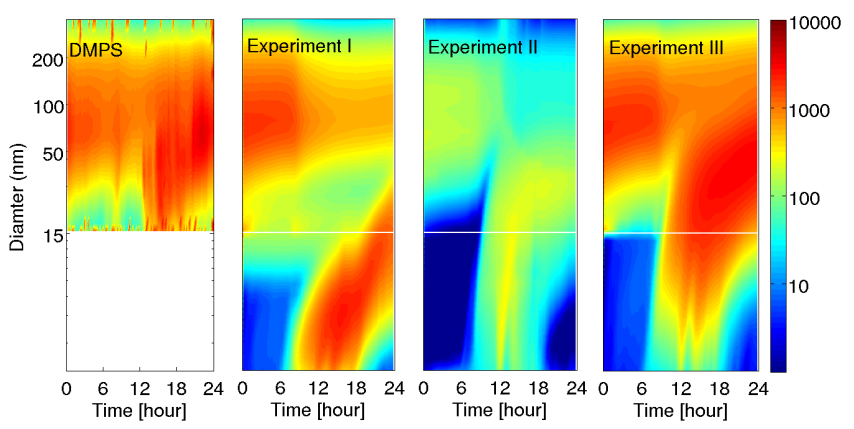

Figure 9. Averaged 1-day number size distributions based on the DMPS measurements and model experiments I-III. The concentration unit: molecules $\mathrm{cm}^{-3}$. DMPS instrument has cutoff size at $15 \mathrm{~nm}$. The averages are made only for periods when measurements are available.

Table 1. Saturation vapor concentration of each organic condensing vapor; unit: $\# \mathrm{~cm}^{-3}$.

\begin{tabular}{llll}
\hline & Vapor I & Vapor II & Vapor III \\
\hline Experiment I & 1 & $10^{10}$ & 1 \\
Experiment II & $10^{6}$ & $10^{11}$ & 1 \\
Experiment III & $10^{6}$ & $10^{11}$ & $10^{6}$ \\
\hline
\end{tabular}

The overall outcome of emissions and chemistry is satisfactory in that all relevant aerosol precursor gases are well simulated with respect to the diurnal trends. In theory, underestimation of sulfuric acid concentrations should lead to less SOA formation, but this problem can be compensated for during the sensitivity studies of the nucleation coefficient.

\section{Aerosol simulations}

The saturation vapor concentrations of organic condensing vapors (vapors I, II, and III) in two model experiments are listed in Table 1. The simulation results provide strong evidence that BVOCs play an important role in particle growth at MEFO (Fig. 9). In experiment I, despite using a very low saturation vapor concentration of 1 molecule $\mathrm{cm}^{-3}$ for vapor I (OH oxidation products of monoterpenes), the model simulated insufficient growth for particles to reach $15 \mathrm{~nm}$, which is the minimum detectable size of the DMPS instrument used during the campaign. The saturation vapor concentration for the ozone oxidation products (vapor II) cannot be less than $10^{10}$ molecules $\mathrm{cm}^{-3}$ due to its high concentration during the night; otherwise it would cause unrealistic nighttime particle growth (Fig. 8). With the same consideration, the saturation vapor concentration of vapor II in experiment II was also kept quite high, at $10^{11}$ molecules $\mathrm{cm}^{-3}$. In experiment II, nucleated clusters are able to grow large enough to pass the instrument detection limit, but the particles do not continue to grow strongly enough in the evening. 
Table 2. Stable reaction products of $\mathrm{OH}, \mathrm{O}_{3}$ and $\mathrm{NO}_{3}$ oxidation of monoterpenes and ozone based on MCM chemistry.

\begin{tabular}{llll}
\hline & $\mathrm{OH}$ & $\mathrm{O}_{3}$ & $\mathrm{NO}_{3}$ \\
\hline \multirow{2}{*}{ Monoterpenes } & LIMAO2 LIMBO2 & LIMOOA LIMBOO & NLIMO2 NBPINAO2 \\
& LIMCO2 BPINAO2 & C92302 NOPINOOA & NBPINBO2 NAPINAO2 \\
& BPINBO2 BPINCO2 & NOPINONE NAPINOOA & NAPINBO2 \\
& APINAO2 APINBO2 & NAPINOOB & \\
MBO & APINCO2 & & NMBOAO2 NMBOBO2 \\
& MBOAO2 MBOBO2 & IBUTALOH MBOOO & \\
\hline
\end{tabular}

Since there is no MBO source during the night, there should be some other aerosol precursor gases present, for example, monoterpenes. Experiment III combined the contributions from the oxidation products of both monoterpenes and $\mathrm{MBO}$ - the $\mathrm{OH}$ oxidation products from $\mathrm{MBO}$ enable the freshly nucleated particles in the daytime to grow large and fast enough, while the nighttime $\mathrm{NO}_{3}$ oxidation products from monoterpenes allow particles to grow up to $100 \mathrm{~nm}$. The simulated growth of particles above $15 \mathrm{~nm}$ compares well with the DMPS measurements. These simulations are also consistent with results from Levin et al. $(2012,2014)$ for hygroscopicity measurements at the BEACHON-ROCS site; these authors showed that growth of new particles was likely driven by biogenic secondary organic species, and the NPF events ultimately impacted aerosol chemical and physical properties for particles up to cloud condensation nuclei (CCN) sizes.

Since lump sums of different oxidation products were used as the condensing vapors in this modeling study, it was not possible to assign exact physical properties to the vapors. Based on the implemented chemistry scheme, the molar mass of the three condensing vapors should range from 200 to $300 \mathrm{Da}$. The saturation vapor concentration of $10^{6}$ molecules $\mathrm{cm}^{-3}$ would thus correspond to approximately $0.0001-0.0005 \mu \mathrm{g} \mathrm{m}^{-3}$, which is close to the saturation vapor concentration of the extremely low volatility compounds suggested by Donahue et al. (2011). The three experiments suggest the importance of extremely low volatility compounds for growing particles, especially the role of monoterpenes and MBO as precursor gases at different times of day.

Particle number size distributions are shown together with above-canopy wind direction observations for the period of 19 to 22 August 2010 (DOY 231 to 234, Fig. 10), when continuous sulfuric acid, MBO and monoterpene concentration measurements were available (Fig. 11). We see that the modeled onset of nucleation, the first appearance of sub- $3 \mathrm{~nm}$ particles in simulated number size distribution, usually starts when the wind direction changes from south to north. This is consistent with the fact that the source of anthropogenic influence is from the Denver area northeast of the site. Anthropogenic $\mathrm{SO}_{2}$ is advected to the forest and is oxidized to $\mathrm{H}_{2} \mathrm{SO}_{4}$ on the way. The $\mathrm{H}_{2} \mathrm{SO}_{4}$ then triggers nucleation. We see the $\mathrm{H}_{2} \mathrm{SO}_{4}$ concentration rise in tandem with the

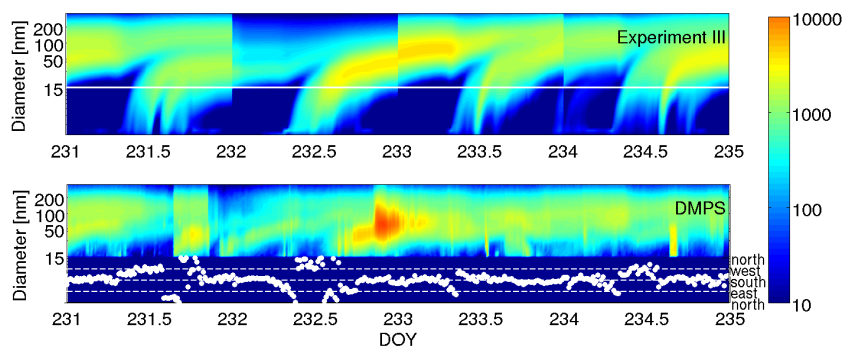

Figure 10. Particle number size distribution from 19 August 2010 (DOY 231) to 22 August 2010 (DOY 234) based on the model experiment III (top) and DMPS measurements (bottom). The DMPS instrument has a $15 \mathrm{~nm}$ lower detection limit. Particle concentration units: molecules $\mathrm{cm}^{-3}$. Observation of wind direction at $30 \mathrm{~m}$ is plotted as white dots in the lower portion of the bottom figure.

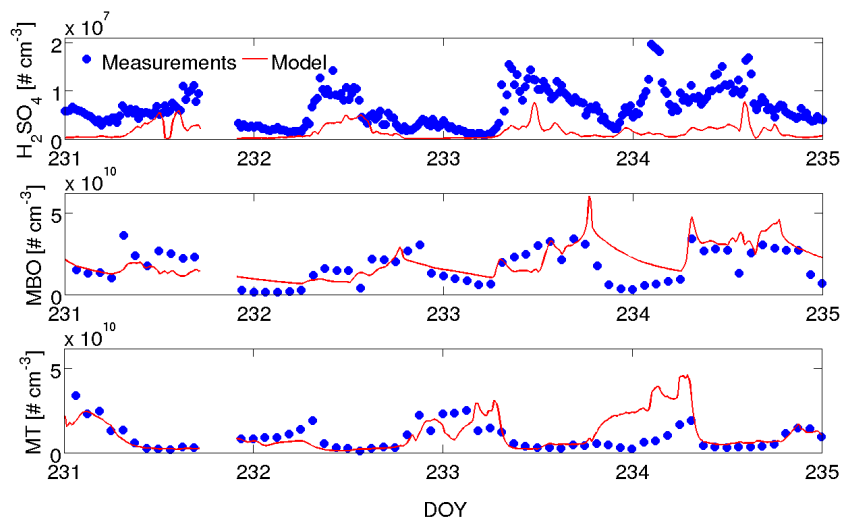

Figure 11. Modeled and measured $\mathrm{H}_{2} \mathrm{SO}_{4}$ (top), $\mathrm{MBO}$ (middle) and monoterpene (MT, bottom) concentrations from 19 August 2010 (DOY 231) to 22 August 2010 (DOY 234). Data were removed for late afternoon-early evening of day 231 to exclude influence from precipitation for $2 \mathrm{~h}$ after precipitation ended. Measurements are shown as blue circles, and the model simulations are indicated by the red line. Comparisons for sulfuric acid are made at $2 \mathrm{~m}$; comparisons for MBO and MT are made at $3.5 \mathrm{~m}$.

change in wind direction. On 19 August 2010 (DOY 231) around noon the wind direction changed from west to northeast and to north. At the same time as the air mass changed, we see a decrease in the concentration of measured back- 
ground particles larger than $100 \mathrm{~nm}$. At that time a burst of particles between 20 and $50 \mathrm{~nm}$ was observed. These particles were likely formed north of the measurement site and then brought to the site through advection. A few hours later at about 19:00:00 LT, a short rain quickly washed out most particles. This burst of particles before the rain matched well with the simulated particle number size distribution for the same time period. We suspect that a new particle formation event did occur in the forest on that day but was just not captured by the measurement instrument. In the evening, particles were removed by precipitation. Similarly on $20 \mathrm{Au}-$ gust 2010 (DOY 232), when the wind direction fluctuated between north and south and the air mass was transported around the forest, we see a burst of particles between 20 and $50 \mathrm{~nm}$ in the afternoon. For the rest of the day the particles were observed to continue growing while wind persisted blowing from the south. The southern wind was likely to bring polluted air to the site in the late evening, which appeared as the high concentration of particles between 50 and $100 \mathrm{~nm}$. Apart from this abrupt increase in concentrations of $50-100 \mathrm{~nm}$ particles, which cannot be captured by the column model, the observed number size distribution is well simulated. Although no new particle formation was observed on 21 August 2010 (DOY 233), the model simulated a weak formation event. This tendency of the model to predict new particle formation events when none are observed has already been reported in the previous SOSAA model study by Zhou et al. (2014). It likely results from our incomplete understanding of the NPF phenomenon, especially in cluster nucleation. Kinetic nucleation parameterization by sulfuric acid is indeed too simple to account for the process, which makes the simulated nucleation too sensitive to sulfuric acid concentration. On 22 August 2010 (DOY 234), the DMPS instrument captured Aitken mode particles for just a short period of about an hour, and the model simulation shows the same distribution at the same time. The high MBO concentration observed on that day also favored SOA formation. We thus suspect that the particles were forming in the area but the instrument failed to capture the complete process due to the strong turbulence in the forest.

\section{Conclusion}

We applied the 1-D chemical-transport model with detailed aerosol dynamics, SOSAA, to simulate results obtained during the summer 2010 BEACHON-ROCS campaign at Manitou Forest Observatory. The model succeeded in reconstructing the meteorological conditions and several important gas species including $\mathrm{OH}, \mathrm{MBO}$ and monoterpenes during the daytime. Although the latest Criegee reaction rates have been included, sulfuric acid concentration is still underestimated by $50 \%$ compared to the measurements.

The SOSAA model indicated that mixing strength and chemistry can be reasonably predicted, and so aerosol sim- ulations were then conducted in order to investigate particle growth. Due to the assumption of horizontal homogeneity for a column model, there is some uncertainty due to the incomplete description of the area's complex terrain and inhomogeneous forest composition. Nevertheless, model simulations are useful for investigating SOA formation, depicting the phenomenon with less influence of horizontal advection, which can hamper our direct field observations. By diluting the advection effects via averaging, Fig. 9 presents a possible pattern of particle growth at the site based on measurements and a successful reproduction of the phenomenon by a stateof-the-art model incorporating the latest knowledge of the processes involved. The modeled results emphasize the contribution from local BVOC emissions to the particle growth. It is indicated that the organic condensing compounds responsible for the growth of ultrafine particles may have a low saturation vapor concentration around $10^{6}$ molecules $\mathrm{cm}^{-3}$. The compounds should have a similar daily pattern and concentration level to the $\mathrm{OH}$ oxidation products of $\mathrm{MBO}$, which is the dominant locally emitted biogenic compound. The concentrations of monoterpene oxidation products are found to be insufficient for growing the ultrafine particles during daytime, but their contribution to the particle loading during nighttime could be important. Due to the anthropogenic origin of $\mathrm{SO}_{2}$, which is the precursor gas of sulfuric acid that triggers nucleation, the model study suggests that new particle formation events are likely to happen locally in the forest in the meantime under the influence of anthropogenic pollution.

The SOSAA model has been shown as a good tool for studying various atmospheric processes, including SOA formation constrained by observations. The model is expected to improve in several aspects, one of which is the growth parameterization. At the moment the chosen condensing molecules are lumped to several condensing vapor classes and assigned with approximated properties. A new parameterization that calculates the exact physical properties, such as saturation vapor pressure, for each specific condensing molecule is being developed.

Acknowledgements. We would like to thank the National Center for Atmospheric Research (NCAR) Advanced Study Programme, the Helsinki University Centre of Environment (HENVI), the EC Seventh Framework Program (Marie Curie Reintegration program, "ALP-AIR", grant no. 334084) and the Nordic Centers of Excellence CRAICC for their generous financial support. We would like to acknowledge participants in the NCAR BEACHON project for data sharing. We wish to express thanks to our colleagues for all the discussions, especially to Sasha Madronich, Tuomo Nieminen and Sam Hall for the valuable suggestions. We thank CSC-IT Center, Finland, for providing the computing service. The National Center for Atmospheric Research is sponsored by the United States National Science Foundation. Any opinions, findings and conclusions or recommendations expressed in the publication are those of the authors and do not necessarily reflect the views of the 
National Science Foundation.

Edited by: R. Holzinger

\section{References}

Allan, J. D., Alfarra, M. R., Bower, K. N., Coe, H., Jayne, J. T., Worsnop, D. R., Aalto, P. P., Kulmala, M., Hyötyläinen, T., Cavalli, F., and Laaksonen, A.: Size and composition measurements of background aerosol and new particle growth in a Finnish forest during QUEST 2 using an Aerodyne Aerosol Mass Spectrometer, Atmos. Chem. Phys., 6, 315-327, doi:10.5194/acp-6-315-2006, 2006.

Andreae, M. O. and Crutzen, P. J.: Atmospheric Aerosols: Biogeochemical Sources and Role in Atmospheric Chemistry, Science, 276, 1052-1058, doi:10.1126/science.276.5315.1052, 1997.

Atkinson, R.: Gas-phase tropospheric chemistry of organic compounds, J. Phys. Chem. Ref. Data, 2, 1-216, 1994.

Atkinson, R.: Atmospheric chemistry of VOCs and $\mathrm{NO}_{x}$, Atmos. Environ., 34, 2063-2101, 2000.

Berresheim, H., Adam, M., Monahan, C., O’Dowd, C., Plane, J. M. C., Bohn, B., and Rohrer, F.: Missing $\mathrm{SO}_{2}$ oxidant in the coastal atmosphere? - observations from high-resolution measurements of $\mathrm{OH}$ and atmospheric sulfur compounds, Atmos. Chem. Phys., 14, 12209-12223, doi:10.5194/acp-14-12209-2014, 2014.

Boy, M., Kulmala, M., Ruuskanen, T. M., Pihlatie, M., Reissell, A., Aalto, P. P., Keronen, P., Dal Maso, M., Hellen, H., Hakola, H., Jansson, R., Hanke, M., and Arnold, F.: Sulphuric acid closure and contribution to nucleation mode particle growth, Atmos. Chem. Phys., 5, 863-878, doi:10.5194/acp-5-863-2005, 2005.

Boy, M., Karl, T., Turnipseed, A., Mauldin, R. L., Kosciuch, E., Greenberg, J., Rathbone, J., Smith, J., Held, A., Barsanti, K., Wehner, B., Bauer, S., Wiedensohler, A., Bonn, B., Kulmala, M., and Guenther, A.: New particle formation in the Front Range of the Colorado Rocky Mountains, Atmos. Chem. Phys., 8, 15771590, doi:10.5194/acp-8-1577-2008, 2008.

Boy, M., Sogachev, A., Lauros, J., Zhou, L., Guenther, A., and Smolander, S.: SOSA - a new model to simulate the concentrations of organic vapours and sulphuric acid inside the ABL Part 1: Model description and initial evaluation, Atmos. Chem. Phys., 11, 43-51, doi:10.5194/acp-11-43-2011, 2011.

Boy, M., Mogensen, D., Smolander, S., Zhou, L., Nieminen, T., Paasonen, P., Plass-Dülmer, C., Sipilä, M., Petäjä, T., Mauldin, L., Berresheim, H., and Kulmala, M.: Oxidation of $\mathrm{SO}_{2}$ by stabilized Criegee intermediate $(\mathrm{sCI})$ radicals as a crucial source for atmospheric sulfuric acid concentrations, Atmos. Chem. Phys., 13, 3865-3879, doi:10.5194/acp-13-3865-2013, 2013.

Chan, A. W. H., Galloway, M. M., Kwan, A. J., Chhabra, P. S., Keutsch, F. N., Wennberg, P. O., Flagan, R. C. and Seinfeld, J. H.: Photooxidation of 2-Methyl-3-Buten-2-ol (MBO) as a Potential Source of Secondary Organic Aerosol, Environ. Sci. Technol., 43, 4647-4652, 2009.

Cui, Y. Y., Hodzic, A., Smith, J. N., Ortega, J., Brioude, J., Matsui, H., Levin, E. J. T., Turnipseed, A., Winkler, P., and de Foy, B.: Modeling ultrafine particle growth at a pine forest site influenced by anthropogenic pollution during BEACHON-RoMBAS 2011, Atmos. Chem. Phys., 14, 11011-11029, doi:10.5194/acp14-11011-2014, 2014.
Damian, V., Sandu, A., Damian, M., Potra, F., and Carmichael, G. R.: The kinetic preprocessor KPP-a software environment for solving chemical kinetics, Comput. Chem. Eng., 26, 1567-1579, 2002.

Dee, D. P., Uppala, S. M., Simmons, A. J., Berrisford, P., Poli, P., and Kobayashi, S.: The ERA-Interim reanalysis: Configuration and performance of the data assimilation system, Q. J. Roy. Meteor. Soc., 137, 553-597, 2011.

DiGangi, J. P., Boyle, E. S., Karl, T., Harley, P., Turnipseed, A., Kim, S., Cantrell, C., Maudlin III, R. L., Zheng, W., Flocke, F., Hall, S. R., Ullmann, K., Nakashima, Y., Paul, J. B., Wolfe, G. M., Desai, A. R., Kajii, Y., Guenther, A., and Keutsch, F. N.: First direct measurements of formaldehyde flux via eddy covariance: implications for missing in-canopy formaldehyde sources, Atmos. Chem. Phys., 11, 10565-10578, doi:10.5194/acp-1110565-2011, 2011.

Donahue, N. M., Trump, E. R., Pierce, J. R., and Riipinen, I.: Theoretical constraints on pure vapor-pressure driven condensation of organics to ultrafine particles, Geophys. Res. Lett., 38, L16801, doi:10.1029/2011GL048115, 2011.

Ehn, M., Thornton, J. A., Kleist, E., Sipilä, M., Junninen, H., Pullinen, I., Springer, M., Rubach, F., Tillmann, R., Lee, B., Lopez-Hilfiker, F., Andres, S., Acir, I., Rissanen, M., Jokinen, T., Schobesberger, S., Kangasluoma, J., Kontkanen, J., Nieminen, T., Kurten, T., Nielsen, L. B., Jorgensen, S., Kjaergaard, H. G., Canagaratna, M., Maso, M. D., Berndt, T., Petäjä, T., Wahner, A., Kerminen, V., Kulmala, M., Worsnop, D. R., Wildt, J., and Mentel, T. F.: A large source of low-volatility secondary organic aerosol, Nature, 506, 476-479, 2014.

Eisele, F. L. and Tanner, D. J.: Measurement of the gas phase concentration of $\mathrm{H}_{2} \mathrm{SO}_{4}$ and methane sulfonic acid and estimates of $\mathrm{H}_{2} \mathrm{SO}_{4}$ production and loss in the atmosphere, J. Geophys. Res.Atmos., 98, 9001-9010, doi:10.1029/93JD00031, 1993.

Fuentes, J. D., Gu, L., Lerdau, M., Atkinson, R., Baldocchi, D., Bottenheim, J. W., Ciccioli, P., Lamb, B., Geron, C., Guenther, A., Sharkey, T. D., and Stockwell, W.: Biogenic Hydrocarbons in the Atmospheric Boundary Layer: A Review, B. Am. Meteorol. Soc., 81, 1537-1575, 2000.

Guenther, A., Hewitt, C. N., Erickson, D., Fall, R., Geron, C., Graedel, T., Harley, P., Klinger, L., Lerdau, M., Mckay, W. A., Pierce, T., Scholes, B., Steinbrecher, R., Tallamraju, R., Taylor, J., and Zimmerman, P.: A global model of natural volatile organic compound emissions, J. Geophys. Res.-Atmos., 100, 8873-8892, doi:10.1029/94JD02950, 1995.

Guenther, A., Karl, T., Harley, P., Wiedinmyer, C., Palmer, P. I., and Geron, C.: Estimates of global terrestrial isoprene emissions using MEGAN (Model of Emissions of Gases and Aerosols from Nature), Atmos. Chem. Phys., 6, 3181-3210, doi:10.5194/acp-63181-2006, 2006.

Guenther, A. B., Jiang, X., Heald, C. L., Sakulyanontvittaya, T., Duhl, T., Emmons, L. K., and Wang, X.: The Model of Emissions of Gases and Aerosols from Nature version 2.1 (MEGAN2.1): an extended and updated framework for modeling biogenic emissions, Geosci. Model Dev., 5, 1471-1492, doi:10.5194/gmd-51471-2012, 2012.

Hansel, A., Jordan, A., Holzinger, R., Prazeller, P., Vogel, W., and Lindinger, W.: Proton transfer reaction mass spectrometry: online trace gas analysis at the ppb level, Int. J. Mass Spectrom., 149-150, 609-619, 1995. 
Harley, P., Fridd-Stroud, V., Greenberg, J., Guenther, A. and Vasconcellos, P.: Emission of 2-methyl-3-buten-2-ol by pines: A potentially large natural source of reactive carbon to the atmosphere, J. Geophys. Res., 103, 25479-25486, doi:10.1029/98JD00820, 1998.

Harley, P., Eller, A., Guenther, A., and Monson, R.: Observations and models of emissions of volatile terpenoid compounds from needles of ponderosa pine trees growing in situ: control by light, temperature and stomatal conductance, Oecologia, 176, 35-55, 2014.

Hoyle, C. R., Boy, M., Donahue, N. M., Fry, J. L., Glasius, M., Guenther, A., Hallar, A. G., Huff Hartz, K., Petters, M. D., Petäjä, T., Rosenoern, T., and Sullivan, A. P.: A review of the anthropogenic influence on biogenic secondary organic aerosol, Atmos. Chem. Phys., 11, 321-343, doi:10.5194/acp-11-321-2011, 2011.

Isidorov, V.: Organic Chemistry of the Earth's Atmosphere, Springer-Verlag, Berlin, 1990.

Jenkin, M. E., Saunders, S. M., and Pilling, M. J.: The tropospheric degradation of volatile organic compounds: a protocol for mechanism development, Atmos. Environ., 31, 81-104, 1997.

Jenkin, M. E., Wyche, K. P., Evans, C. J., Carr, T., Monks, P. S., Alfarra, M. R., Barley, M. H., McFiggans, G. B., Young, J. C., and Rickard, A. R.: Development and chamber evaluation of the MCM v3.2 degradation scheme for $\beta$-caryophyllene, Atmos. Chem. Phys., 12, 5275-5308, doi:10.5194/acp-12-52752012, 2012.

Junkermann, F., Platt, U., and Volz-Thomas, A.: A photoelectric detector for the measurement of photolysis frequencies of ozone and other atmospheric molecules, J. Atmos. Chem., 8, 203-227, 1989.

Jung, J., Miyazaki, Y., and Kawamura, K.: Different characteristics of new particle formation between urban and deciduous forest sites in Northern Japan during the summers of 2010-2011, Atmos. Chem. Phys., 13, 51-68, doi:10.5194/acp-13-51-2013, 2013.

Karl, T., Kaser, L., and Turnipseed, A.: Eddy covariance measurements of isoprene and 232-MBO based on $\mathrm{NO}^{+}$time-of-flight mass spectrometry, Int. J. Mass Spectrom., 365-366, 15-19, 2014.

Kaser, L., Karl, T., Guenther, A., Graus, M., Schnitzhofer, R., Turnipseed, A., Fischer, L., Harley, P., Madronich, M., Gochis, D., Keutsch, F. N., and Hansel, A.: Undisturbed and disturbed above canopy ponderosa pine emissions: PTR-TOF-MS measurements and MEGAN 2.1 model results, Atmos. Chem. Phys., 13, 11935-11947, doi:10.5194/acp-13-11935-2013, 2013a.

Kaser, L., Karl, T., Schnitzhofer, R., Graus, M., Herdlinger-Blatt, I. S., DiGangi, J. P., Sive, B., Turnipseed, A., Hornbrook, R. S., Zheng, W., Flocke, F. M., Guenther, A., Keutsch, F. N., Apel, E., and Hansel, A.: Comparison of different real time VOC measurement techniques in a ponderosa pine forest, Atmos. Chem. Phys., 13, 2893-2906, doi:10.5194/acp-13-2893-2013, 2013 b.

Kerminen, V., Virkkula, A., Hillamo, R., Wexler, A. S., and Kulmala, M.: Secondary organics and atmospheric cloud condensation nuclei production, J. Geophys. Res.-Atmos., 105, 92559264, doi:10.1029/1999JD901203, 2000.

Kerminen, V., Lihavainen, H., Komppula, M., Viisanen, Y., and Kulmala, M.: Direct observational evidence linking atmospheric aerosol formation and cloud droplet activation, Geophys. Res. Lett., 32, L14803, doi:10.1029/2005GL023130, 2005.
Kerminen, V.-M., Petäjä, T., Manninen, H. E., Paasonen, P., Nieminen, T., Sipilä, M., Junninen, H., Ehn, M., Gagné, S., Laakso, L., Riipinen, I., Vehkamäki, H., Kurten, T., Ortega, I. K., Dal Maso, M., Brus, D., Hyvärinen, A., Lihavainen, H., Leppä, J., Lehtinen, K. E. J., Mirme, A., Mirme, S., Hõrrak, U., Berndt, T., Stratmann, F., Birmili, W., Wiedensohler, A., Metzger, A., Dommen, J., Baltensperger, U., Kiendler-Scharr, A., Mentel, T. F., Wildt, J., Winkler, P. M., Wagner, P. E., Petzold, A., Minikin, A., Plass-Dülmer, C., Pöschl, U., Laaksonen, A., and Kulmala, M.: Atmospheric nucleation: highlights of the EUCAARI project and future directions, Atmos. Chem. Phys., 10, 10829-10848, doi:10.5194/acp-10-10829-2010, 2010.

Kim, S., Karl, T., Guenther, A., Tyndall, G., Orlando, J., Harley, P., Rasmussen, R., and Apel, E.: Emissions and ambient distributions of Biogenic Volatile Organic Compounds (BVOC) in a ponderosa pine ecosystem: interpretation of PTR-MS mass spectra, Atmos. Chem. Phys., 10, 1759-1771, doi:10.5194/acp-101759-2010, 2010.

Kim, S., Wolfe, G. M., Mauldin, L., Cantrell, C., Guenther, A., Karl, T., Turnipseed, A., Greenberg, J., Hall, S. R., Ullmann, K., Apel, E., Hornbrook, R., Kajii, Y., Nakashima, Y., Keutsch, F. N., DiGangi, J. P., Henry, S. B., Kaser, L., Schnitzhofer, R., Graus, M., Hansel, A., Zheng, W., and Flocke, F. F.: Evaluation of HOx sources and cycling using measurement-constrained model calculations in a 2-methyl-3-butene-2-ol (MBO) and monoterpene (MT) dominated ecosystem, Atmos. Chem. Phys., 13, 20312044, doi:10.5194/acp-13-2031-2013, 2013.

Kirkby, J., Curtius, J., Almeida, J., Dunne, E., Duplissy, J., Ehrhart, S., Franchin, A., Gagne, S., Ickes, L., Kurten, A., Kupc, A., Metzger, A., Riccobono, F., Rondo, L., Schobesberger, S., Tsagkogeorgas, G., Wimmer, D., Amorim, A., Bianchi, F., Breitenlechner, M., David, A., Dommen, J., Downard, A., Ehn, M., Flagan, R. C., Haider, S., Hansel, A., Hauser, D., Jud, W., Junninen, H., Kreissl, F., Kvashin, A., Laaksonen, A., Lehtipalo, K., Lima, J., Lovejoy, E. R., Makhmutov, V., Mathot, S., Mikkila, J., Minginette, P., Mogo, S., Nieminen, T., Onnela, A., Pereira, P., Petäjä, T., Schnitzhofer, R., Seinfeld, J. H., Sipilä, M., Stozhkov, Y., Stratmann, F., Tome, A., Vanhanen, J., Viisanen, Y., Vrtala, A., Wagner, P. E., Walther, H., Weingartner, E., Wex, H., Winkler, P. M., Carslaw, K. S., Worsnop, D. R., Baltensperger, U., and Kulmala, M.: Role of sulphuric acid, ammonia and galactic cosmic rays in atmospheric aerosol nucleation, Nature, 476, 429-433, 2011.

Korhonen, H., Lehtinen, K. E. J., and Kulmala, M.: Multicomponent aerosol dynamics model UHMA: model development and validation, Atmos. Chem. Phys., 4, 757-771, doi:10.5194/acp-4757-2004, 2004.

Kulmala, M. and Kerminen, V.: On the formation and growth of atmospheric nanoparticles, Atmos. Res., 90, 132-150, 2008.

Kulmala, M., Toivonen, A., Mäkelä, J. M., and Laaksonen, A.: Analysis of the growth of nucleation mode particles observed in Boreal forest, Tellus B, 50, 449-462, 1998.

Kulmala, M., Laakso, L., Lehtinen, K. E. J., Riipinen, I., Dal Maso, M., Anttila, T., Kerminen, V.-M., Hõrrak, U., Vana, M., and Tammet, H.: Initial steps of aerosol growth, Atmos. Chem. Phys., 4, 2553-2560, doi:10.5194/acp-4-2553-2004, 2004a.

Kulmala, M., Vehkamäki, H., Petäjä, T., Dal Maso, M., Lauri, A., Kerminen, V.-M., Birmili, W., and McMurry, P. H.: Formation and growth rates of ultrafine atmospheric particles: a review of observations, J. Aerosol Sci., 35, 143-176, 2004b. 
Kulmala, M., Kontkanen, J., Junninen, H., Lehtipalo, K., Manninen, H. E., Nieminen, T., Petäjä, T., Sipilä, M., Schobesberger, S., Rantala, P., Franchin, A., Jokinen, T., Järvinen, E., Äijälä, M., Kangasluoma, J., Hakala, J., Aalto, P. P., Paasonen, P., Mikkilä, J., Vanhanen, J., Aalto, J., Hakola, H., Makkonen, U., Ruuskanen, T., Mauldin, R. L., Duplissy, J., Vehkamäki, H., Bäck, J., Kortelainen, A., Riipinen, I., Kurtén, T., Johnston, M. V., Smith, J. N., Ehn, M., Mentel, T. F., Lehtinen, K. E. J., Laaksonen, A., Kerminen, V., and Worsnop, D. R.: Direct Observations of Atmospheric Aerosol Nucleation, Science, 339, 943946, doi:10.1126/science.1227385, 2013.

Laaksonen, A., Kulmala, M., O’Dowd, C. D., Joutsensaari, J., Vaattovaara, P., Mikkonen, S., Lehtinen, K. E. J., Sogacheva, L., Dal Maso, M., Aalto, P., Petäjä, T., Sogachev, A., Yoon, Y. J., Lihavainen, H., Nilsson, D., Facchini, M. C., Cavalli, F., Fuzzi, S., Hoffmann, T., Arnold, F., Hanke, M., Sellegri, K., Umann, B., Junkermann, W., Coe, H., Allan, J. D., Alfarra, M. R., Worsnop, D. R., Riekkola, M.-L., Hyötyläinen, T., and Viisanen, Y.: The role of VOC oxidation products in continental new particle formation, Atmos. Chem. Phys., 8, 2657-2665, doi:10.5194/acp-82657-2008, 2008.

Lamarque, J.-F., Bond, T. C., Eyring, V., Granier, C., Heil, A., Klimont, Z., Lee, D., Liousse, C., Mieville, A., Owen, B., Schultz, M. G., Shindell, D., Smith, S. J., Stehfest, E., Van Aardenne, J., Cooper, O. R., Kainuma, M., Mahowald, N., McConnell, J. R., Naik, V., Riahi, K., and van Vuuren, D. P.: Historical (1850-2000) gridded anthropogenic and biomass burning emissions of reactive gases and aerosols: methodology and application, Atmos. Chem. Phys., 10, 7017-7039, doi:10.5194/acp10-7017-2010, 2010.

Lauros, J., Sogachev, A., Smolander, S., Vuollekoski, H., Sihto, S.L., Mammarella, I., Laakso, L., Rannik, Ü., and Boy, M.: Particle concentration and flux dynamics in the atmospheric boundary layer as the indicator of formation mechanism, Atmos. Chem. Phys., 11, 5591-5601, doi:10.5194/acp-11-5591-2011, 2011.

Levin, E. J. T., Prenni, A. J., Petters, M. D., Kreidenweis, S. M., Sullivan, R. C., Atwood, S. A., Ortega, J., DeMott, P. J., and Smith, J. N.: An annual cycle of size-resolved aerosol hygroscopicity at a forested site in Colorado, J. Geophys. Res.-Atmos., 117, D06201, doi:10.1029/2011jd016854, 2012.

Levin, E. J. T., Prenni, A. J., Palm, B. B., Day, D. A., CampuzanoJost, P., Winkler, P. M., Kreidenweis, S. M., DeMott, P. J., Jimenez, J. L., and Smith, J. N.: Size-resolved aerosol composition and its link to hygroscopicity at a forested site in Colorado, Atmos. Chem. Phys., 14, 2657-2667, doi:10.5194/acp-14-26572014, 2014.

Lindinger, W., Hansel, A., and Jordan, A.: On-line monitoring of volatile organic compounds at pptv levels by means of protontransfer-reaction mass spectrometry (PTR-MS) medical applications, food control and environmental research, Int. J. Mass Spectrom., 173, 191-241, 1998.

Lohmann, U. and Feichter, J.: Global indirect aerosol effects: a review, Atmos. Chem. Phys., 5, 715-737, doi:10.5194/acp-5-7152005, 2005.

Madronich, S.: UV radiation in the natural and perturbed atmosphere, Environmental Effects of UV (Ultraviolet) Radiation, edited by: Evini, M., Lewis Publisher, Boca Raton, 17-69, 1993.
Madronich, S. and Flocke, S.: The role of solar radiation in atmospheric chemistry, in: Handbook of Environmental Chemistry, edited by: Boule, P., Sringer-Verlag, Heidelberg, 1998.

Mauldin III, R. L., Berndt, T., Sipilä, M., Paasonen, P., Petäjä, T., Kim, S., Kurtén, T., Stratmann, F., Kerminen, V.-.M., and Kulmala, M.: A new atmospherically relevant oxidant of sulphur dioxide, Nature, 488, 193-196, 2012.

Mogensen, D., Smolander, S., Sogachev, A., Zhou, L., Sinha, V., Guenther, A., Williams, J., Nieminen, T., Kajos, M. K., Rinne, J., Kulmala, M., and Boy, M.: Modelling atmospheric OH-reactivity in a boreal forest ecosystem, Atmos. Chem. Phys., 11, 97099719, doi:10.5194/acp-11-9709-2011, 2011.

Mogensen, D., Gierens, R., Crowley, J. N., Keronen, P., Smolander, S., Sogachev, A., Nölscher, A. C., Zhou, L., Kulmala, M., Tang, M. J., Williams, J., and Boy, M.: Simulations of atmospheric $\mathrm{OH}, \mathrm{O}_{3}$ and $\mathrm{NO}_{3}$ reactivities within and above the boreal forest, Atmos. Chem. Phys., 15, 3909-3932, doi:10.5194/acp-15-39092015, 2015.

Nakashima, Y., Kato, S., Greenberg, J., Harley, P., Karl, T., Turnipseed, A., Apel, E., Guenther, A., Smith, J., and Kajii, Y.: Total $\mathrm{OH}$ reactivity measurements in ambient air in a southern Rocky mountain ponderosa pine forest during BEACHONSRM08 summer campaign, Atmos. Environ., 85, 1-8, 2014.

Ortega, I. K., Olenius, T., Kupiainen-Määttä, O., Loukonen, V., Kurtén, T., and Vehkamäki, H.: Electrical charging changes the composition of sulfuric acid-ammonia/dimethylamine clusters, Atmos. Chem. Phys., 14, 7995-8007, doi:10.5194/acp-14-79952014, 2014.

Paasonen, P., Nieminen, T., Asmi, E., Manninen, H. E., Petäjä, T., Plass-Dülmer, C., Flentje, H., Birmili, W., Wiedensohler, A., Hõrrak, U., Metzger, A., Hamed, A., Laaksonen, A., Facchini, M. C., Kerminen, V.-M., and Kulmala, M.: On the roles of sulphuric acid and low-volatility organic vapours in the initial steps of atmospheric new particle formation, Atmos. Chem. Phys., 10, 11223-11242, doi:10.5194/acp-10-11223-2010, 2010.

Pierce, J. R. and Adams, P. J.: Uncertainty in global CCN concentrations from uncertain aerosol nucleation and primary emission rates, Atmos. Chem. Phys., 9, 1339-1356, doi:10.5194/acp-91339-2009, 2009.

Pirjola, L., Kulmala, M., Wilck, M., Bischoff, A., Stratmann, F., and Otto, E.: Formation of sulphuric acid aerosols and cloud condensation nuclei: an expression for significant nucleation and model comparison, J. Aerosol Sci., 30, 1079-1094, 1999.

Plass-Dülmer, C., Elste, T., Paasonen, P., and Petäjä, T.: Sulphuric acid measurements by CIMS - uncertainties and consistency between various data sets, Geophys. Res. Abstr., EGU2011-11681, EGU General Assembly 2011, Vienna, Austria, 2011.

Riipinen, I., Pierce, J. R., Yli-Juuti, T., Nieminen, T., Häkkinen, S., Ehn, M., Junninen, H., Lehtipalo, K., Petäjä, T., Slowik, J., Chang, R., Shantz, N. C., Abbatt, J., Leaitch, W. R., Kerminen, V.-M., Worsnop, D. R., Pandis, S. N., Donahue, N. M., and Kulmala, M.: Organic condensation: a vital link connecting aerosol formation to cloud condensation nuclei $(\mathrm{CCN})$ concentrations, Atmos. Chem. Phys., 11, 3865-3878, doi:10.5194/acp-11-38652011, 2011.

Saunders, S. M., Jenkin, M. E., Derwent, R. G., and Pilling, M. J.: Protocol for the development of the Master Chemical Mechanism, MCM v3 (Part A): tropospheric degradation of non- 
aromatic volatile organic compounds, Atmos. Chem. Phys., 3, 161-180, doi:10.5194/acp-3-161-2003, 2003.

Schobesberger, S., Junninen, H., Bianchi, F., Lönn, G., Ehn, M., Lehtipalo, K., Dommen, J., Ehrhart, S., Ortega, I. K., Franchin, A., Nieminen, T., Riccobono, F., Hutterli, M., Duplissy, J., Almeida, J., Amorim, A., Breitenlechner, M., Downard, A. J., Dunne, E. M., Flagan, R. C., Kajos, M., Keskinen, H., Kirkby, J., Kupc, A., Kürten, A., Kurtén, T., Laaksonen, A., Mathot, S., Onnela, A., Praplan, A. P., Rondo, L., Santos, F. D., Schallhart, S., Schnitzhofer, R., Sipilä, M., Tomé, A., Tsagkogeorgas, G., Vehkamäki, H., Wimmer, D., Baltensperger, U., Carslaw, K. S., Curtius, J., Hansel, A., Petäjä, T., Kulmala, M., Donahue, N. M., and Worsnop, D. R.: Molecular understanding of atmospheric particle formation from sulfuric acid and large oxidized organic molecules, Proc. Natl. Acad. Sci. USA., 110, 1722317228, doi:10.1073/pnas.1306973110, 2013.

Sellegri, K., Hanke, M., Umann, B., Arnold, F., and Kulmala, M.: Measurements of organic gases during aerosol formation events in the boreal forest atmosphere during QUEST, Atmos. Chem. Phys., 5, 373-384, doi:10.5194/acp-5-373-2005, 2005.

Seroji, A. R., Webb, A. R., Coe, H., Monks, P. S., and Rickard, A. R.: Derivation and validation of photolysis rates of $\mathrm{O}_{3}, \mathrm{NO}_{2}$, and $\mathrm{CH}_{2} \mathrm{O}$ from a GUV-541 radiometer, J. Geophys. Res.-Atmos., 109, D21307, 10.1029/2004JD004674, 2004.

Sharkey, T. D., Wiberley, A. E., and Donohue, A. R.: Isoprene Emission from Plants: Why and How, Ann. Botany, 101, 5-18, doi:10.1093/aob/mcm240, 2008.

Sihto, S.-L., Kulmala, M., Kerminen, V.-M., Dal Maso, M., Petäjä, T., Riipinen, I., Korhonen, H., Arnold, F., Janson, R., Boy, M., Laaksonen, A., and Lehtinen, K. E. J.: Atmospheric sulphuric acid and aerosol formation: implications from atmospheric measurements for nucleation and early growth mechanisms, Atmos. Chem. Phys., 6, 4079-4091, doi:10.5194/acp-6-4079-2006, 2006.

Sipilä, M., Berndt, T., Petäjä, T., Brus, D., Vanhanen, J., Stratmann, F., Patokoski, J., Mauldin, R. L., Hyvärinen, A., Lihavainen, H., and Kulmala, M.: The Role of Sulfuric Acid in Atmospheric Nucleation, Science, 327, 1243-1246, doi:10.1126/science.1180315, 2010.

Smolander, S., He, Q., Mogensen, D., Zhou, L., Bäck, J., Ruuskanen, T., Noe, S., Guenther, A., Aaltonen, H., Kulmala, M., and Boy, M.: Comparing three vegetation monoterpene emission models to measured gas concentrations with a model of meteorology, air chemistry and chemical transport, Biogeosciences, 11, 5425-5443, doi:10.5194/bg-11-5425-2014, 2014.

Sogachev, A., Menzhulin, G. V., Heimann, M., and Lloyd, J.: A simple three-dimensional canopy-planetary boundary layer simulation model for scalar concentrations and fluxes, Tellus B, 54, doi:10.3402/tellusb.v54i5.16729, 2002.
Sogachev, A., Kelly, M., and Leclerc, M.: Consistent Two-Equation Closure Modelling for Atmospheric Research: Buoyancy and Vegetation Implementations, Bound.-Lay. Meteorol., 145, 307327, 2012.

Spracklen, D. V., Jimenez, J. L., Carslaw, K. S., Worsnop, D. R., Evans, M. J., Mann, G. W., Zhang, Q., Canagaratna, M. R., Allan, J., Coe, H., McFiggans, G., Rap, A., and Forster, P.: Aerosol mass spectrometer constraint on the global secondary organic aerosol budget, Atmos. Chem. Phys., 11, 12109-12136, doi:10.5194/acp-11-12109-2011, 2011.

Tanner, D. J., Jefferson, A., and Eisele, F. L.: Selected ion chemical ionization mass spectrometric measurement of $\mathrm{OH}$, J. Geophys. Res. Atmos., 102, 6415-6425, doi:10.1029/96JD03919, 1997.

Weber, R. J., Marti, J. J., McMurry, P. H., Eisele, F. L., Tanner, D. J., and Jefferson, A.: Measurements of new particle formation and ultrafine particle growth rates at a clean continental site, J. Geophys. Res. Atmos., 102, 4375-4385, doi:10.1029/96JD03656, 1997.

Welz, O., Savee, J. D., Osborn, D. L., Vasu, S. S., Percival, C. J., Shallcross, D. E., and Taatjes, C. A.: Direct Kinetic Measurements of Criegee Intermediate (CH2OO) Formed by Reaction of CH2I with $\mathrm{O}_{2}$, Science, 335, 204-207, doi:10.1126/science.1213229, 2012.

Zhang, H., Worton, D. R., Lewandowski, M., Ortega, J., Rubitschun, C. L., Park, J., Kristensen, K., Campuzano-Jost, P., Day, D. A., Jimenez, J. L., Jaoui, M., Offenberg, J. H., Kleindienst, T. E., Gilman, J., Kuster, W. C., de Gouw, J., Park, C., Schade, G. W., Frossard, A. A., Russell, L., Kaser, L., Jud, W., Hansel, A., Cappellin, L., Karl, T., Glasius, M., Guenther, A., Goldstein, A. H., Seinfeld, J. H., Gold, A., Kamens, R. M., and Surratt, J. D.: Organosulfates as Tracers for Secondary Organic Aerosol (SOA) Formation from 2-Methyl-3-Buten-2-ol (MBO) in the Atmosphere, Environ. Sci. Technol., 46, 9437-9446, 2012.

Zhang, H., Zhang, Z., Cui, T., Lin, Y. H., Bhathela, N. A., Ortega, J., Worton, D. R., Goldstein, A. H., Guenther, A., Jimenez, J. L., Gold, A., and Surratt, J. D.: Secondary Organic Aerosol Formation via 2-Methyl-3-buten-2-ol Photooxidation: Evidence of Acid-Catalyzed Reactive Uptake of Epoxides, Environ. Sci. Technol. Lett., 1, 242-247, doi:10.1021/ez500055f, 2014.

Zhang, R., Suh, I., Zhao, J., Zhang, D., Fortner, E. C., Tie, X., Molina, L. T., and Molina, M. J.: Atmospheric New Particle Formation Enhanced by Organic Acids, Science, 304, 1487-1490, doi:10.1126/science.1095139, 2004.

Zhou, L., Nieminen, T., Mogensen, D., Smolander, S., Rusanen, A., Kulmala, M., and Boy, M.: SOSAA - a new model to simulate the concentrations of organic vapours, sulphuric acid and aerosols inside the ABL - Part 2: Aerosol dynamics and one case study at a boreal forest site, Boreal Environ. Res., 19B, 237-256, 2014. 